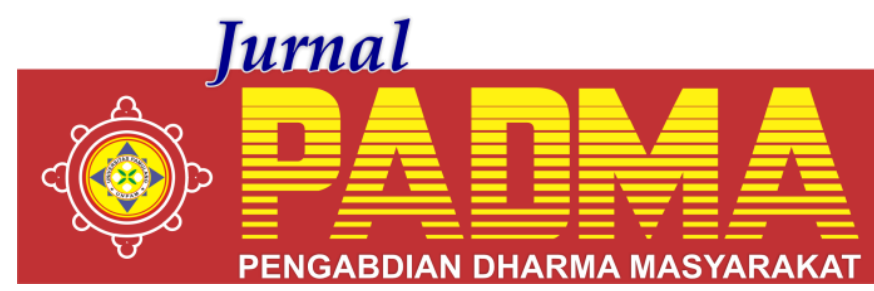

VOLUME I, NOMOR 3, JULI 2021

\title{
PEMBERDAYAAN ANAK-ANAK MELALUI PELATIHAN KARAKTER BUILDING DENGAN PEMANFAATAN TABUNGAN SEJAK USIA DINI DI ASRAMA YATIM PUTRA MIZAN AMANAH BINTARO TANGERANG
}

\author{
1Sugiyanto, ${ }^{2}$ Budi Suhendar, ${ }^{3 *}$ Sulistiawati, ${ }^{4}$ Anita Nurul Firdaus, ${ }^{5}$ Ronaldo Budiarto \\ Universitas Pamulang, Tangerang Selatan, Banten, Indonesia \\ *wsulistia240@gmail.com
}

\begin{abstract}
Abstrak
Pengabdian kepada Masyarakat ini bekerjasama dengan lembaga amil zakat mizan amanah di jl. Bintaro Utama 3 Blok AP No.50A, Bintaro, Kec. Pd. Aren, Kota Tangerang Selatan, Banten 15221. Tujuan dilaksanakan PKM untuk memberikan pengetahuan dalam hal pelatihan karakter building dengan pemanfaatan tabungan sejak dini. Metode yang digunakan dalam pengabdian ini adalah bercerita, diskusi, dan pemberian materi mengenai karakter building dan kiat-kiat untuk menabung sejak dini guna mempersiapkan diri unuk mewujudkan impian masa depan. Kesimpulan dari pengabdian kepada masyarakat di lembaga amil zakat mizan Amanah adalah membutuhkan pendampingan dalam penerapan system menabung sejak dini., Dukungan dan pendampingan dapat dimulai dari pembentukan karakter building bagi anak-anak asrama yatim putra mizan amanah.
\end{abstract}

Kata Kunci: Manajemen Keuangan, Tabungan, Manajemen SDM, Pembentukan Karakter

\section{Abstract}

This Community Service collaborates with the amil zakat institution mizan amanah on Jl. Bintaro Utama 3 Block AP No. 50A, Bintaro, Kec. Pd. Aren, South Tangerang City, Banten 15221. The purpose of PKM is to provide knowledge in terms of character building training by utilizing savings from an early age. The method used in this service is storytelling, discussion, and providing material about character building and tips for saving from an early age to prepare yourself to realize future dreams. The conclusion of community service at the Mizan Amanah amil zakat institution is that it requires assistance in implementing the saving system from an early age.

Keywords: Financial Management, Savings, Human Resourch Management, Character Building

\section{PENDAHULUAN}

Perkembangan perilaku dan sikap anak-anak yang telah mengalami modernisasi digital sudah mulai luntur karakter tradisionalnya karena sudah mulai terpengaruh dengan budaya modern yang kurang tepat untuk diterapkan pada anakanak usia dini. Anak-anak usia dini akan menerapkan dan menirukan apa yang dipandang oleh matanya, apabila anak-anak usia dini tidak diberikan bimbingan dan diarahkan hal-hal mana saja yang baik dan patut untuk dilakukan serta meninggalkan hal-hal yang kurang baik untuk dilakukan pada usianya. Anak-anak usia dini memperoleh bimbingan pembelajaran utama yang berasal dari lingkungan keluarga. Peran keluarga dalam mendidik generasi menjadi modal besar sebagai penentu masa depan. Tanpa ada sentuhan keluarga, sangat sulit bagi siapapun untuk berkembang dan memiliki mimpi masa depan yang gemilang.

Bagaimana dengan anak-anak yang hari ini tidak memiliki keluarga. Para generasi yang tidak tersentuh pendiddikannya karena kondisi keluarga yang serba kekurangan. Kondisi yang seperti itu pasti ada bahkan banyak jumlahnya di inonesia ini. Hal ini menjadi tantangan pemerintah dan semua elemen dalam mencari solusi dari kondisi anak-anak tersebut. Anak-anak yang kurang beruntung dalam hal keluarga dan terdaftar dalam anggota Asrama yatim Mizan Amanah akan berikan pendampingan dalam pembelajaran, Asrama yatim Mizan Amanah merupakan sarana yang dibangun untuk membantu mendidik generasi muda terkhusus anakanak yatim dan dhuafa untuk menggapai 
cita-cita sebagai penentu masa depan bangsa.

Asrama yatim mizan amanah merupakan sarana yang dibangun untuk membantu mendidik generasi muda terkhusus anak-anak yatim dan dhuafa untuk menggapai cita-cita sebagai penentu masa depan bangsa. Keluarga merupakan lingkungan pendiidkan paling utama sebagai penentu keberhasilan pencetakan generasi. Keluarga menjadi elemen utama untuk merangkai sebuah pondasi pada diri anak atau manusia. Putih, abu, hitam adalah Selain menanamkan nilai karakter, fasilitator juga melakukan kegiatan refleksi nilai-nilai karakter yang sudah diimplementasikan pada kehidupan sehar-hari. Pada kegiatan ini anak asuh diminta untuk menggambarkan secara deskriptif apa yang telah mereka implementasikan pada kehidupan seharihari. Supaya program ini tetep berlanjut ke depannya, fasilitator memberikan modul pembelajaran pendidikan karakter dan pelatihan karakter building perencanaan tabungan untuk meraih cita-cita di masa mendatang, poster edukasi, dan media belajar pada asrama yatim dhuafa mizan amanah.

Peranan anak-anak usia dini sebagai agen penerus bangsa tidak dapat dipisahkan dari upaya untuk mempersiapkan masa depan mereka dalam mensejahterakan bangsa. Untuk mewujudkan pertumbuhan generasi muda yang dapat mengangkat kesejahteraan bagi anak-anak yatim dan dhuafa di mizan amanah maka perlu untuk merancang dan mempersiapkan untuk masa depan bagi anak-anak tersebut melalui program pelatihan karakter building dan pemanfaatan tabungan untuk anak usia dini. Salah satu indikator meningkatnya kesejahteraan bagi anak-anak usia dini di asrama mizan amanah adalah mempersiapkan masa depan melalui proses menabung yang dapat diterapkan sejak dini. warna yang ditentukan keluarga kepada generasinya. Melihat kondisi yang ada maka muncul rasa prihatin pada anak-anak usia dini tersebut, sehingga dirasa perlu untuk melakukan bimbingan dan pelatihan karakter building untuk pemanfaatan tabungan.

Program kepada masyarakat (pkm) ini memberikan layanan bimbingan dan pelatihan karakter building pada pemanfaatan tabungan sejak dini. Bimbingan dan pelatihan diberikan melalui bimbingan kelompok dengan metode story telling dan menonton video motivasi supaya dapat diterapkan dalam kehidupan sehari-hari, baik dilingkungan asrama, sekolah, maupun masyarakat. Nilai-nilai karakter yang akan disampaikan yaitu bersyukur dan berterima kasih, saling memuji, empati, mengatasi konflik, jujur, disiplin, bertanggung jawab, dan tabungan serta membuat perencanaan keuangan atau tabungan untuk masa depan. Pelatihan yang diberikan menyesuaikan objek sasaran yaitu anak-anak asrama mizan amanah yang berada pada jenjang sekolah dasar. Layanan bimbingan dan pelatihan diberikan dengan suasana dan kondisi yang ceria disesuaikan dengan objek sasaran anak-anak usia dini. Kegiatan yang akan berlangsung tidak hanya diikuti oleh mahasiswa dan para anak-anak asrama yatim mizan amanah melainkan pihak pengelola yayasan juga turut terlibat dan berkontribusi dalam memonitor setiap kegiatan anak asuh. Sebagai bentuk pengawasan kegiatan, anak asuh memaparkan dan menjelaskan kembali perihal yang telah dipahami dari materi yang telah disampaikan dan melakukan story telling dan menonton video motivasi karakter building dan meraih impian melalui tabungan. Harapannya, anak asuh mampu memahami materi yang diberikan oleh fasilitator (mahasiswa) melalui layanan bimbingan dan pelatihan karakter building untuk pemanfaatan tabungan sejak dini. Melalui program bimbingan dan pelatihan diharapkan masa depan yang gemilang bagi anak-anak di asrama yatim mizan amanah dapat tercapai.

Kemandirian finansial merupakan salah satu komponen masukan instrumental (instrumental input) yang sangat penting dalam penyelenggaraan Pendidikan, salah satu bagian dari kemandirian finansial adalah menabung. Setiap upaya pencapaian tujuan pendidikan, baik tujuan-tujuan yang bersifat kuantitaif maupun kualitatif, finansial pendidikan memiliki peranan yang sangat menentukan. Hampir tidak ada upaya pendidikan yang dapat mengabaikan peranan finansial tersebut. Sehingga dapat 
dikatakan tanpa finansial, proses pendidikan tidak akan berjalan.

Cara menanamkan nilai-nilai karakter sekolah dibagi ke dalam beberapa bentuk kegiatan, antara lain kegiatan rutin, kegiatan spontan, keteladanan dan juga pengondisian. Kegiatan ini akan menjadi budaya dan berpengaruh dalam pembentukan karakter peserta didik. Lingkungan sekolah juga sangat dibutuhkan dalam pembentukan karakter. Di samping keluarga sebagai pusat pendidikan, lingkungan sekolahpun berfungsi dalam membentuk kepribadian peserta didik yang diharapkan dapat merubah perilakunya menjadi lebih positif sesuai yang diharapkan. Lingkungan sekolah juga tempat yang signifikan bagi peserta didik dalam tahap perkembangannya dan merupakan sebuah lingkungan sosial yang berpengaruh bagi kehidupan mereka (Wibowo, 2012).

Membangun tiga karakter (character building) adalah proses mengukir atau memahat jiwa sedemikian rupa, sehingga 'berbentuk' unik, menarik, dan berbeda atau dapat dibedakan dengan orang lain. Ibarat sebuah huruf dalam alfabet yang tak pernah sama antara yang satu dengan yang lain, demikianlah orang-orang yang berkarakter dapat dibedakan satu dengan yang lainnya (termasuk dengan yang tidak/belum berkarakter atau 'berkarakter' tercela). (Harefa, 2010)

Berdasarkan keterangan latar belakang tersebut, kami Mahasiswa/i dari Program Studi Magister Manajemen Universitas Pamulang mengadakan kegiatan Pengabdian kepada Masyarakat dengan bekerjasama dengan Lembaga amil zakat mizan amanah membantu untuk pemberikan pengetahuan dan sosialisai untuk melatih pembentukan karakter building dan melatih kebiasaan menabung sejak dini.

Kegiatan pengabdian yang berfokus pada pembentukan karakter building dan melatih kebiasaan menabung sejak dini bagi anak-anak asuh di asrama mizan Amanah. Memberikan pemaaman bahwa untuk meraih impian tidak hanya menunggu saja rezeki itu datang, menjemput rezeki dengan menciptakan dan merealisasikan ide-ide cemerlang serta menerapkan kebiasaan menabung sejak dini dapat membantu untuk mempersiapkan diri dalam merealisasikan impian mereka.

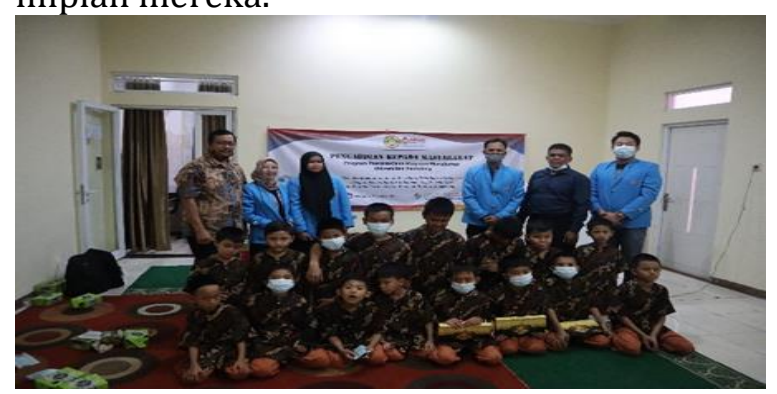

Gambar 1. Foto bersama dengan ketua pengasuh asrama mizan amanah, Dosen Pembimbing, Peserta PKM, dan Anggota Yayasan

\section{METODE}

Metode yang digunakan dalam kegiatan PKM ini adalah :

1. Pengumpulan informasi/data di lembaga amil zakat mizan amanah. Pengumpulan informasi dilakukan dengan wawancara dengan pengasuh asrama.

2. Pelatihan, diskusi dan menonton dengan topic karakter building dan membentuk karakter system menabung untuk meujudkan impian.

3. Evaluasi Program yang telah dijalankan oleh asrama.

Adapun waktu dan pelakasanaan kegiatan sebagai berikut :

1. Pelaksanaan kegiatan Minggu, 1 November 2020.

2. Tempat pelaksanaan Lembaga amil zakat asrama yatim putra Mizan Amanah, Jl. Bintaro Utama 3 Blok AP No. 50A, Bintaro, Kec. Pd. Aren, Kota Tangerang Selatan, Banten

3. Jumlah Peserta sebanyak 30 orang anak asrama dan pengurus asrama.

4. Tim pengabdian masyarakat terdiri atas 1 orang dosen dan 4 mahasiswa Program Studi Magister manajemen Universitas Pamulang.

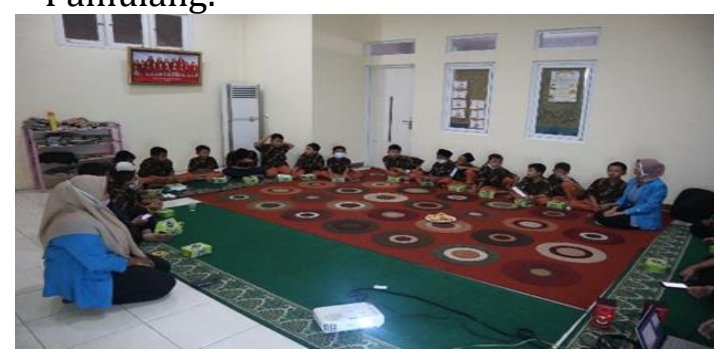

Gambar 2. Tim PKM dan peserta pelatihan karakter building dan pemanfaatan tabungan 
HASIL DAN PEMBAHASAN

\section{Persiapan dan Pembekalan}

Pada tahapan Persiapan dan pembekalan tim dosen berdiskusi mengenai tahapan awal sebelum pelaksanaan PKM dilaksanakan. Tahapantahapan tersebut diuraikan sebagai berikut:

a. Tim Dosen berdiskusi untuk menentukan mahasiswa yang akan berpartisipasi dalam kegiatan pengabdian. Mahasiswa dipilih berdasarkan kemampuan yang sesuai dengan tema kegiatan yang diusung.

b. Tim dosen kemudian memberikan pelatihan kepada mahasiswa mengenai materi yang akan disampaikan, selanjutnya dilakukan pembagian tim untuk menentukan tugas masingmasing mahasiswa.

c. Mahasiswa melakukan kunjungan ke Lembaga amil zakat asrama yatim mizan amanah untuk berkoordinasi dan berdiskusi lebih lanjut dengan pihak asrama mengenai teknis pelaksanaan pelatihan materi dan mengetahui kegiatan anak-anak asrama serta mempersiapkan sarana dan prasarana yang dibutuhkan ketika pelaksanaan pengabdian.

d. Teknis pelaksanaan penyampaian materi pelatihan

\section{Pelaksanaan Kegiatan}

Kegiatan pelatihan materi dasar pembentukan karakter building dan pemanfaatan sistem tabungan. Durasi pelaksanaaan lima jam. Dimulai dari jam 09.00 WIB sampai dengan 13.00 WIB.

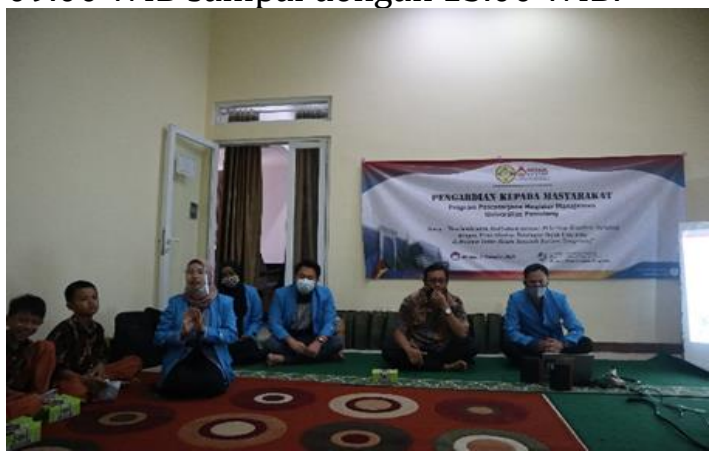

Gambar 3. Penyampaian materi oleh Mahasiswa

Berikut uraian pelaksanaan kegiatan pengabdian di Asrama Yatim Mizan Amanah Bintaro Tangerang : a. Tim Abdimas berangkat menuju asrama yatim putra Mizan Amanah.

b. Sambutan dari Ketua pelaksana Pengabdian kepada Masyarakat, sambutan dosen pembimbing dan ketua pengasuh asrama mizan Amanah.

c. Pengkondisian peserta; meliputi pengaturan tempat duduk peserta, persiapan sebelum seminar oleh ketua kelompok Pengabdian Masrakat, seperti salam hormat dan membaca doa dan membaca Al-quran.

d. Penyampaian materi pelatihan oleh dosen dan mahasiswa kepada siswa sebagai bentuk pelaksanaan program pengabdian

e. Evaluasi. Setelah dilakukan pelatihan materi pembentukan karakter building dan pemanfaatan tabungan selanjutnya dilakukan evaluasi peserta mengenai materi yang telah disampaikan yaitu dengan diskusi dan tanya jawab terkait materi yang disampaikan. Pada evaluasi ini peserta diminta untuk memberanikan dirinya maju dan mereview kembali materi yang telah disampaikan selama tiga pertemuan ini.

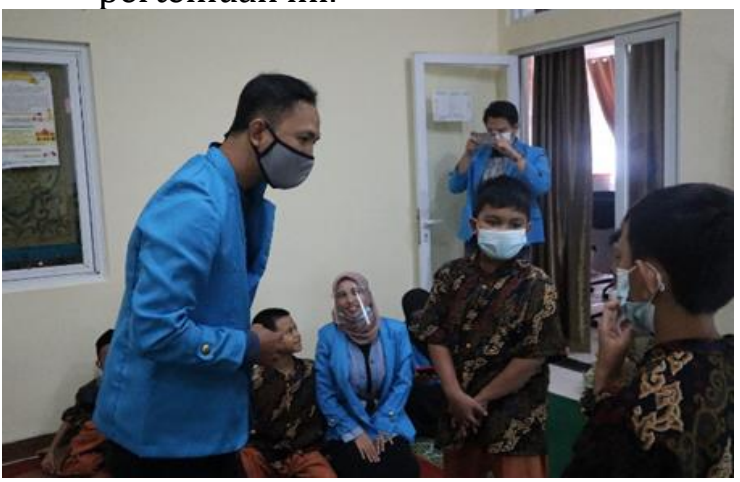

Gambar 4. Diskusi dan review materi.

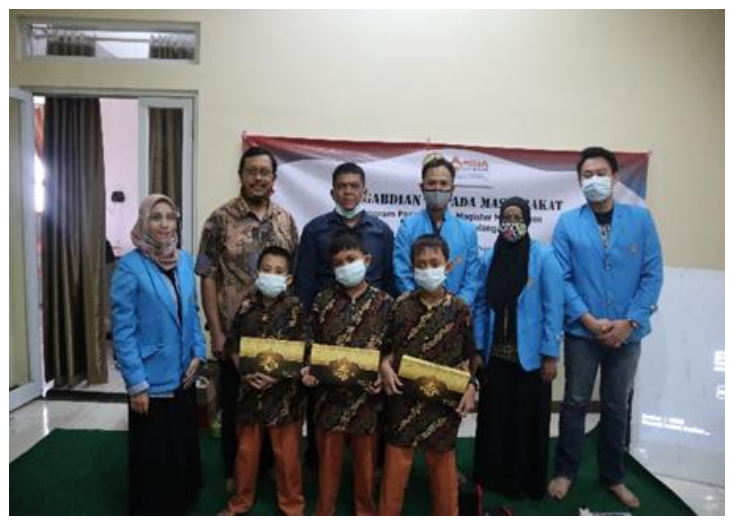

Gambar 5. Pemberian Hadiah kepada Peserta 


\section{PENUTUP}

\section{KESIMPULAN}

1. Kesimpulan tentang materi metode pembelajaran karakter building dan pemanfaatan tabungan sejak dini. Membentuk karakter kemandirian dan disiplin bagi anak-anak asrama. Mempelajari konsep dan kemampuan berfkir kritis anak-anak untuk melakukan hal-hal perilaku terpuji.

2. Pengabdian kepada masyarakat dalam membentuk suatu karakter building bagi anak-anak asrama yaim mizan Amanah serta pelitihan untuk membiasakan diri menabung sejak usia dini.

\section{SARAN}

1. Pengurus membentuk karakter building sejak dini pada anak-anak panti asuhan dengan cara pemnfaatan tabungan.

2. Pengurus dapat menyampaikan adanya dampak pendidikan karakter building serta pemanfaatan tabungan pada usia dini terhadap anak-anak panti asuhan untuk menggapai cita-cita dari apa yang sudah dipersiapkan.

\section{DAFTAR PUSTAKA}

Harefa, A.2010. Mindset Therapy: Terapi Pola Pikir, tentang Makna Learn,Unlearn, dan Relearn. Gramedia Pustaka Utama, Jakarta.
Majid, A. 2011. Perencanaan Pembelajaran Mengembangkan Standar Kompetensi Guru. Remaja Rosdakarya, Bandung.

Nurjaya, N., Sunarsi, D., Effendy, A. A., Teriyan, A., \& Gunartin, G. (2021). Pengaruh Etos Kerja Dan Disiplin Kerja Terhadap Kinerja Pegawai Pada Dinas Kehutanan Dan Perkebunan Kota Bogor. JENIUS (Jurnal Ilmiah Manajemen Sumber Daya Manusia), 4(2), 172-184.

Pangestu.1998. Statistik Induktif. Edisi IV. Yogyakarta: BPFE.Engel, et al. 2000. Perilaku Konsumen. Terj.F.X. Budianto. Jakarta : Binarupa Aksara.

Rovika, dini. 2019. Hubungan Budaya Sekolah Dan Lingkungan Sekolah Dengan Pembentukan Karakter Peserta Didik Sekolah Dasar. Skripsi: Universitas lampung

Sunarsi, D., Akbar, I. R., Rozi, A., Khoiri, A., \& Salam, R. (2021). The Influence of Motivation and Work Discipline on Employee Performance at the Yogyakarta Tourism Service. Prosiding ICoGEMT, 1(1), 1-7.

Wibowo, A. 2012. Pendidikan Karakter: Strategi Membangun Karakter Bangsa Berperadaban. Pustaka Pelajar, Yogyakarta 